\title{
4th ESTAD (European Steel Technology and Application Days) in Düsseldorf
}

\author{
Bruno Hribernik ${ }^{1}$ and Ronald Schnitzer ${ }^{2}$ \\ ${ }^{1}$ ASMET Research GmbH, Leoben, Austria \\ ${ }^{2}$ Department of Materials Science, Montanuniversität Leoben, Leoben, Austria
}

Published online October 28, 2019

In this issue of the BHM Berg- und Hüttenmännische Monatshefte, selected articles of the 4th ESTAD (European Steel Technology and Application Days) are published.

The ESTAD conference series is hosted in joint cooperation between the Austrian Society for Metallurgy and Materials (ASMET), the Swedish Steel Producers Association (Jernkontoret), Associazione Italiana di Metallurgia (AIM), and the German Steel Institute (VDEh).

The 1st ESTAD took place in Paris, France, in April 2014, the 2nd conference was held together with the International Metallurgical Trade Fair (METEC) in Düsseldorf, Germany, in June 2015, and the 3rd conference was convened in $\mathrm{Vi}$ enna, Austria, in June 2017.

The 4th ESTAD was held in parallel with the 10th International Metallurgical Trade Fair (METEC) 2019 in Düsseldorf, Germany, and started with a get-together in the evening of 24 June 2019 and ended with plant visits on 28 June 2019. During the conference, participants had the opportunity to attend numerous presentations covering the latest technical developments in the world of steel.

Only those who continue to develop their businesses remain competitive. The prerequisite for this development is that companies stay constantly informed about the latest and most sophisticated technological advances, exchanging ideas and initiating and expanding networks with clients, partners and suppliers.

This event offered the opportunity to get information about the most recent developments of steelmaking processes and steel products.

The international conference focused on the latest trends-and provided a wide networking and information platform for equipment and service suppliers, plant manufacturers and steelmakers. The visitors were offered the perfect opportunity to reach their objectives.

\section{R. Schnitzer $(\square)$}

Department of Materials Science, Montanuniversität Leoben, Leoben, Austria

ronald.schnitzer@unileoben.ac.at
At this event, the participants acquired the latest information on new ideas and developments as well as on the state-of-the-art in metallurgical process technologies for iron and steel production, steel materials, and steel application.

In 120 technical sessions within the three days from 25 June to 27 June 2019, approximately 550 technical presentations covered the following fields:

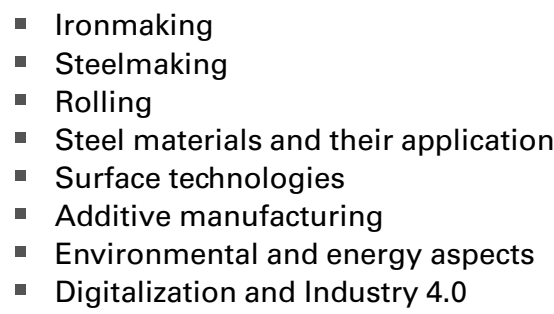

The scientific program included plenary, invited, and contributed lectures from world-leading international scientists from universities and industry.

From all the contributions of the 4th ESTAD, the following papers have been selected for publication in this issue:

- Thomas Bürgler, Johann Prammer: Hydrogen Steelmaking: Technology Options and R\&D Projects

- Victor van Straaten, Bart de Graaff, Edo Engel: Hot Blast System Development: Technology, Operations, Campaign Management

- Roman Krobath, Christian Bernhard, Sergiu llie, Jakob Six, Susanne Hahn, and Paul Pennerstorfer: The Role of Grain Boundary Oxidation on Surface Crack Formation under Continuous Casting Conditions

- Wolfgang Bleck, Fritz Brühl, Yan Ma, Caesar Sasse: Materials and Processes for the Third-generation Advanced High-strength Steels

- Christian Bernhard, Philipp Dorrer, Susanne Michelic, Roman Rössler: The Role of FeTi Addition to Micro-in- 
clusions in the Production of ULC Steel Grades via the $\mathrm{RH}$ Process Route

- F.M. Androsch, U. Redl: How Megatrends Drive Innovation

- Anrin Bhattacharyya: RECYRON®: Idea to Innovation to Technology in Zero-Waste Ironmaking

We would also like to express our special gratitude to all speakers of the 4th ESTAD, especially the authors of this issue. All parties involved have conjointly made it possible for us to stage such an international event.

Finally, we would also like to express our immense gratitude to the conference managers Hans Bodo Lüngen and Peter Dahlmann as well as to their coworkers for all their professional work in the conference organization; without their support and kindness, ESTAD 2019 would not have been possible.

We are certain that the papers presented at the 4th ESTAD and in this issue will enable us to make a significant contribution towards the sustainable development of the ironmaking and steel industry.

ASMET will continue the cooperation with Jernkontoret and other steel societies. Therefore, we are looking for- ward to meeting all of you at the 5th ESTAD (European Steel Technology and Application Days) in The Brewery Conference Centre Stockholm, Sweden, from 14 June to 18 June 2021.

\section{Bruno Hribernik}

Ronald Schnitzer
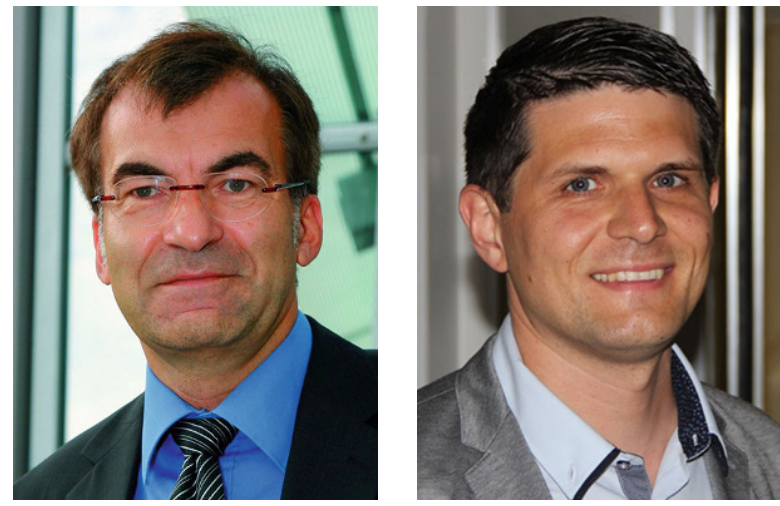

Bruno Hribernik

Ronald Schnitzer 